\title{
Cross-Case Study on the Incentive Mechanism of Co-investment Projects in State Owned Enterprises from the Perspective of Employee Governance
}

\author{
Rong $\operatorname{Lin}^{1}$ \\ ${ }^{1}$ School of Business Administration, South China University of Technology, Guangzhou, Guangdong \\ Province, China
}

Keywords: Employee Governance; Co-Investment Mechanism; State-Owned Enterprises.

\begin{abstract}
Creating investment project is an important measure to increase the intrinsic vitality of state-owned enterprises and promote innovation. Considering the operability and purpose of investment projects, co-investment mechanism is the best choice. This article adopts the perspective of employee governance, using stakeholder theory and human capital theory to analyze co-investment projects in state-owned enterprises. It is found that a co-investment project is a contradictory unity of incentive and restraint for managers. Then, key factors of a successful investment mechanism are analyzed. This study provides theoretical guidance on innovation mechanisms for state-owned enterprises, and plays a certain reference role for the practice of co-investment.
\end{abstract}

\section{Introduction}

Innovation has become a powerful driving force for China's economic development. The state-owned enterprises in China, however, have been strongly restricted by institutional constraints under the background of public ownership leading economy. In innovation performances, the roles of state-owned enterprises employees, especially the core members like key decision makers and project executives, are indispensable. But these employees are seriously neglected in corporate governance. [1] The motivation of state-owned enterprises staff should be improved, too. How to increase the enthusiasm of state-owned enterprises employees through the design of enterprise internal system, so as to improve the level of employee governance, is the problem demanding prompt solution in the innovation practice of state-owned enterprises in China.

The existing researches on employee governance mainly focus on the theoretical basis of employees' participation in governance and the comparison between Chinese and western patterns. Yong-cheng Luo analyzes the latest progresses and achievements on issue of employees' participation in corporate governance, comprehensively interprets various theories on employees' participation in corporate governance, and provides theoretical support for the following research. At present, most studies do not specifically study key factors and major parts of employee governance mechanism in state-owned enterprises. Therefore, this paper attempts to integrate previous researches, analyzes key factors on co-investment mechanism from the perspective of employee governance, and tries to solve the incentive problem of state-owned enterprises.

Based on the comparative study of state-owned enterprises and non-state-owned holding enterprises, this paper attempts to solve the following questions: What are the main factors that make up the mechanism of state-owned enterprises? Which factors can influence core staff? How to combine these factors to achieve a win-win situation between the enterprise and employees, and promote the sustainable development of state-owned enterprises?

\section{Literature Review}

The necessity of co-investment projects. In previous studies, there were many different definitions on employee governance. Some scholars found that the term of "employee's participation in governance" can be used in a broad and a narrow sense. In narrow sense it refers employees' directly or indirectly involvement in the management of enterprises' internal affairs; in broad sense it 
means that staff can partly participate in decision-making, management, supervision and profit distribution processes. [3] Some researchers compared human resource management with human resource governance, and found that human resource governance focuses on the macro level of human resource system. Only by upgrading the human resources management to governance level, can we realize the strategic role of human resources and enhance the status of human resources department in the organization [4]. In a word, the definitions of employee governance focus on a same concept: employees obtain the right of decision making through seeking means of participating in corporate governance.

State owned venture capital firm is the most important organizational form in venture capital industry in the early stage. [5] The reasons of creating co-investment projects in state-owned enterprises are as follows. For constraint concerns, investment projects in state-owned enterprise are long-term projects, which are conducive to the formation of spontaneous monitoring interests which unify managers and team members of the same project, and avoid the implementation of decisions which deviate from the goal of the enterprise. For incentive concerns, the investment values of completed projects are higher; meanwhile, core members of the project do not only have the right of profit distribution, but also possess power of participating in decision making.

Theories of stakeholder and property rights of human capital. There's no universal definition on the connotation of stakeholder theory in the academic field. One theory that accepted by most scholars is, "stakeholder is a person who is able to influence the realization of organizations' goals, or being influenced by the realization of organizations' goals". [7] Stake holding means the relation to the realization of organizations' goals. Co-investment mechanism has constraint and incentive functions to stakeholders. Stakeholders have to take the risk because of their capital investment; but they also enjoy the rights and interests. On one hand, if stakeholders of the venture capital investment projects do not make decisions or implement projects with discretion, the effectiveness of the project will be directly damaged. In that case, co-investment mechanism will play its constraint effect. On the other hand, if stakeholders use their capital properly, and the project obtains a benefit in the end, the co-investment mechanism will be able to play the role of stimulating stakeholders.

After 1950s, American economist Schultz put forward the concept of human capital. As a kind of invisible capital, human capital requires attention, so that the owner of human capital can participate in decision-making. Domestic scholars define human capital property rights from different angles, but they focus on a same concept: property right of human capital is a kind of property right which can reflect its value only in transactions. Thus, it needs to enter enterprises to realize the exchange of property rights [6].

On the level of decision-making and execution, managers and agents in state-owned enterprises are indispensable. From the perspective of human capital property rights, on the one hand, both managers and team members of the project are owners of human capital property rights in venture capital. On the other hand, differentiated incentive mechanism should be made, in order to determine the proportion of property rights according to their contributions to the enterprise.

The practice of employee governance: profit distribution in co-investment mechanism. Although our country has always attached great importance to the management of employees, the status of staff in state-owned enterprises has gone from bad to worse [8]. At present, employee governance in foreign companies has following patterns: 1, employee's participation in co-determination mechanism of decision making; 2, organizing enterprise union, lifetime employment and seniority mechanisms; 3, establishing trade union and employee stock ownership. [9] Some scholars offer suggestions on the practice of employee governance in China. Hui Song put forward to a model on employees' participation in corporate governance in Chinese state-owned enterprise, namely the "harmonious co-determination mechanism based on virtual stock holding". [10]

In general, foreign practice of employee governance is better than Chinese. Although some domestic scholars put forward to the mechanism of harmonious co-determination, they fail to clearly define stakeholders in state-owned enterprises, as well as the residual claim. As the result, employees' 
greatest concern, profit distribution, is difficult to be implemented. It may harm employees' initiative participation and the implementation effect of projects.

\section{Research Methods}

Research design. First of all, this paper takes the method of cross-case study. Each case is an experiment. Then, we interviews with industry leaders and practitioners of investment mechanism to find out key incentive factors in co-investment projects from the perspective of management level. Therefore, we find out relevant economic theory on employee governance firstly, and extract relevant the factors; then match them with key factors extracted from interviews, and find out new factors which serve as supplement to existing theory.

Research cases. In this study, theoretical sampling method is used to make cases typical, and to ensure the availability of data. Selection conditions include the following: financial investment companies which have been implemented co-investment mechanism; all enterprises come from Southern China to improve the internal validity of the study. We select three companies: K Company and Y Company in Guangzhou, and S Company Shenzhen. Basic information can be seen in table 1. The names of companies and respondents are shown as letters.

Table 1 Enterprise Information

\begin{tabular}{|l|c|c|c|}
\hline Enterprise Information & Year Founded & Industry & Ownership \\
\hline K company in Guangzhou & 2000 & Finance & State-owned \\
\hline Y company in Guangzhou & 2011 & Finance & State-owned \\
\hline S company in Shenzhen & 2002 & Finance & State-owned \\
\hline
\end{tabular}

Data collection. In the process of data collection, team members need to filter and sort data for next step. Participants in data collection include a teacher in the field of human resource management, two financial industry employees and two master students. During interviews, they need to observe and estimate whether these data can provide new information. If not, the interview will be suspended. The main sources of data are structured and semi-structured interviews with employees from the three companies. Interviews are conducted from September to October, 2016. The total survey time is 9 hours, while the collected interview data is as long as 30,000 words. The project team conducts interviews with top managers from the three companies, trying to understand the reasons, processes and results of implementing co-investment mechanisms.

Validity and reliability. In order to ensure the quality of this study, we follow the scientific research methods. In the processes of research design, data collection and data analysis, the following methods are adopted to ensure the reliability and validity of research indicators. Specific information can be seen in Table 2

Table 2 Validity and Reliability

\begin{tabular}{|c|c|c|c|}
\hline Target & Strategy & Specific methods & Stage \\
\hline \multirow[b]{2}{*}{ Validity } & $\begin{array}{l}\text { various data } \\
\text { sources }\end{array}$ & $\begin{array}{l}\text { website information, text information } \\
\text { and interview }\end{array}$ & $\begin{array}{l}\text { Data } \\
\text { collection }\end{array}$ \\
\hline & $\begin{array}{l}\text { key persons } \\
\text { review the } \\
\text { outline }\end{array}$ & $\begin{array}{l}\text { experts and interviewers review the } \\
\text { interview outline before each interview }\end{array}$ & $\begin{array}{l}\text { Data } \\
\text { collection }\end{array}$ \\
\hline $\begin{array}{l}\text { Internal } \\
\text { Validity }\end{array}$ & $\begin{array}{l}\text { causal } \\
\text { relationship } \\
\text { framework }\end{array}$ & $\begin{array}{l}\text { causal framework based on literature } \\
\text { and case description }\end{array}$ & $\begin{array}{l}\text { Data } \\
\text { collection }\end{array}$ \\
\hline
\end{tabular}




\begin{tabular}{|c|c|c|c|}
\hline & $\begin{array}{l}\text { pattern } \\
\text { matching }\end{array}$ & $\begin{array}{l}\text { matching based on empirical analysis } \\
\text { and literature analysis }\end{array}$ & Data analysis \\
\hline & $\begin{array}{l}\text { triangular } \\
\text { verification }\end{array}$ & $\begin{array}{l}\text { the theory is explained from different } \\
\text { theories and perspectives }\end{array}$ & Data analysis \\
\hline External & $\begin{array}{l}\text { theory } \\
\text { guidance }\end{array}$ & $\begin{array}{l}\text { research framework is established on } \\
\text { the basis of various existing theories }\end{array}$ & $\begin{array}{l}\text { Research } \\
\text { design }\end{array}$ \\
\hline Validity & $\begin{array}{l}\text { Multiple case } \\
\text { analysis }\end{array}$ & $\begin{array}{l}\text { logic replication between multiple } \\
\text { cases }\end{array}$ & $\begin{array}{l}\text { Research } \\
\text { design }\end{array}$ \\
\hline \multirow[b]{2}{*}{ Reliability } & $\begin{array}{l}\text { case study } \\
\text { outline }\end{array}$ & define research questions & $\begin{array}{l}\text { Research } \\
\text { design }\end{array}$ \\
\hline & $\begin{array}{l}\text { case study } \\
\text { database }\end{array}$ & $\begin{array}{l}\text { database is established to classify data } \\
\text { according to certain criteria }\end{array}$ & $\begin{array}{l}\text { Data analysis } \\
\text { and research } \\
\text { design }\end{array}$ \\
\hline
\end{tabular}

\section{Models of Co-investment Mechanism: the Contradictory Unity of Incentive and Restraint}

Through analyzing the coding characteristics of data, it is found that co-investment mechanism in state-owned enterprises have characteristics of incentive and constraint. The researcher defines these factors, and then concludes the key factors of successful investment mechanism.

Incentive factors. Human capital property right. Through encoding, it is found that in these enterprises, capital property rights indicate the rights employees obtained according to their contribution to the project. Detailed can be seen from the investment proportion of residual rights of control and residual rights of claim. "A proportion would also be set for the investment amount of project leader. Although the combined proportion of team members is relatively high, the averaged number is less than that of the team leader (2-23)". "The investment committee would make the right decision (1-12)". Therefore, property rights of human capital are defined as the rights employees obtained according to their control over and contribution to the success of the project, including the rights they can obtain by investing and the interests they may get after exiting the project.

Reputation of the management team. From the external point of view, we find that the management team has a vital role in the project. Management team with better performance can enhance the trust of investors, and effectively promote financing. "In this industry, the key is the management team. Good management team can create better performance, and raise more money (1-2)". So if the investment project is profitable through risk assessment, and has an effectively management team, another basis of interest will be created.

Constraint factors. Though encoding, we find that constraint factors are mainly reflected in two aspects. One is external, namely the problem of legal and compliance; the other is internal, means the delimitation of stakeholders, in order to bound up group members through interests.

Legal and compliance. Compared to enterprises of other forms of ownership, state-owned enterprises have to address the constraints from legal compliance in co-investment. The state has a clear guidance for their development and their institutions, thus, co-investment projects cannot be in conflict with state laws and regulations. Therefore, "state-owned enterprises are subject to multiple regulatory constraints (1-26)". "Senior executives of state-owned enterprises may hold the stocks of enterprises from the same rank or higher ranks, but not those from lower ranks (2-35)". Those are the statutory provisions of the country. Therefore, only within the scope prescribed by law can co-investment be effectively implemented. 
Stakeholders. At the level of the employee governance, co-investment mechanism focuses on key staff, namely senior managers in the company and team members of the project. Throughout the project period, funds cannot be withdrawn at any time, or can only be withdrawn in a controllable range. This is a risk basis for members. "When managing a company, we need to gather strength from the core management teams and integrate them into one (1-15)". After defining stakeholders, core members are required to follow the investment through interest oriented mechanism. In fact, however, it is to combine the company objectives with the goals of core members, so that they can be constraint for better completing their projects.

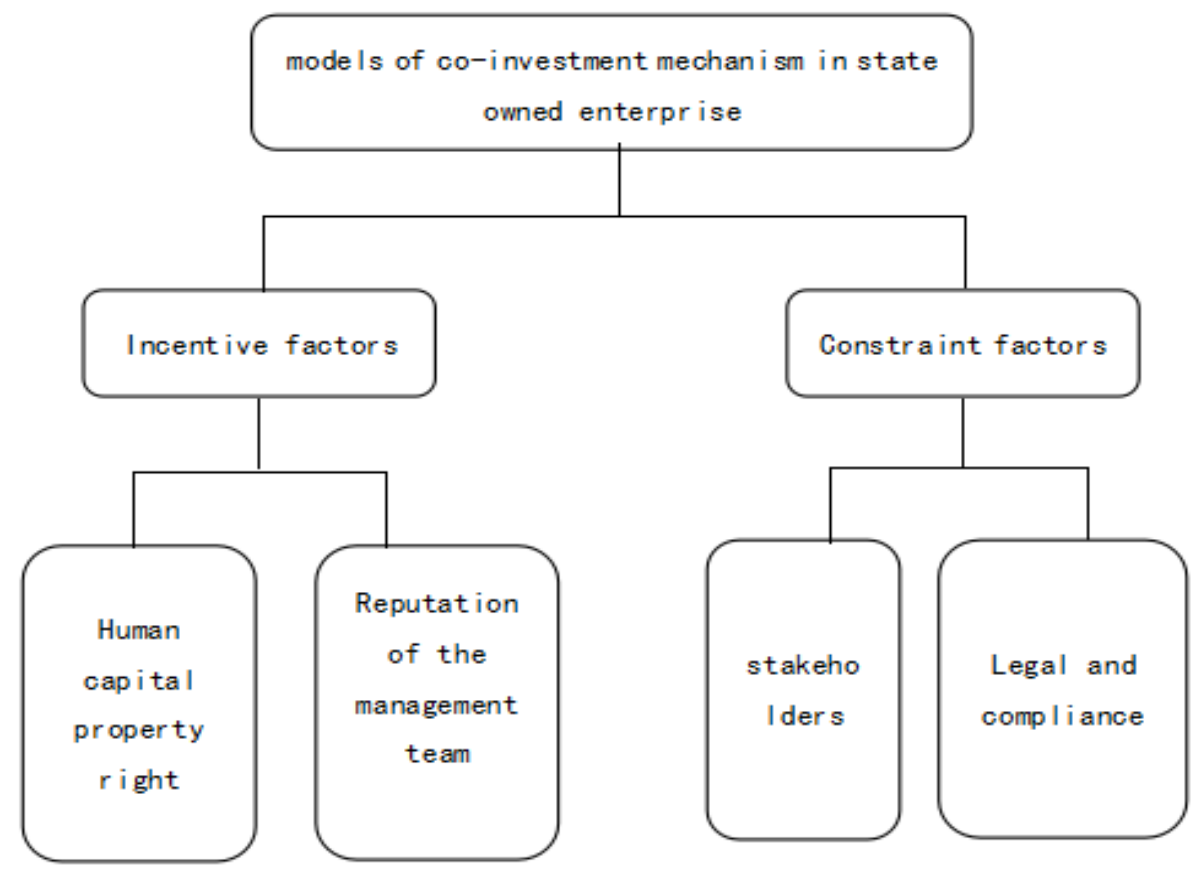

Figure 1. Key factors of co-investment mechanism in state owned enterprises

\section{Conclusions}

Research discussion. Through the cross-case study, we find that co-investment projects of state-owned enterprises perfectly integrate incentive and restraint mechanisms for key staff. From the perspective of employee governance, if the enterprise wants to achieve better performances, it needs to pay attention to the incentive mechanism of key staff first, and then combine enterprise goals with the individual goals of key staff. Key staff should keep the loyalty to the company, and enjoy decision-making rights as well as profit distribution rights.

The human capital values of top managers and core members of the project are relatively high, so they demand more human capital property rights. The reputation of the management team is an interesting discovery made in this study. It means that, the relationship between project and staff does not only include material interests and rights, but also include invisible income. The reputation of team can bring convenience to the career development of group members and improve their financial efficiency. Therefore, human capital property rights and the reputation of management team are two important incentive factors. State owned enterprises are subject to the guidance of the state, and have clear rules and regulations. In investment projects of state-owned enterprises, stakeholders are decision-makers and implementers. It is worth noting that stakeholders are not only the object of corporate constraints, but also the owner of human capital property rights

Research significance. Different from previous studies, this study adopts the perspective of employee governance, which highlights the incentive and constraint of the senior staff and core members. At the same time, combined with human capital property rights theory, stakeholder theory and other economic theories, we try to explain the role of co-investment mechanism. It is found that 
co-investment mechanism is the contradictory unity of incentive and restraint functions. Then we theoretically explain factors that influence the co-investment mechanism.

Through the analysis of internal factors of co-investment mechanism, we can enhance the operability of co-investment mechanism in state-owned enterprises. From the perspective of incentive, when implementing co-investment mechanism, main human capital value owners in the enterprise should be found out to define property rights of human capital. From the perspective of constraint, investment mechanism should be in line with law provisions. Meanwhile, is important to bound interests of the enterprise and the interests of employees to unify the company's business goals and employees' personal goals, and to define compulsory co-investment objects.

Research limitations. Although this study is a cross-case study, all sample companies in this research are selected in Guangdong Province. If we increase sample size and regional differences, the external validity of research can be improved. Secondly, this paper studies key factors of co-investment mechanism, but does not analyze the interactions between these factors. Thirdly, due to the lack of re-tracking investigations, it is impossible to learn the evolution process of co-investment mechanism. Future researches can fill up these research gaps and make new discovery.

\section{References}

[1] Y. Lu: Employee participation: the neglected third party in Chinese enterprise reform----Comment on OECD Corporate Governance Standards 2004 Edition and Draft of State-owned Enterprise Management Guidelines, J. Securities and Futures of China. 8 (2005).

[2] Y.G. Liu, C.F. Wu, Study on issues about employee participation in corporate governance in state owned enterprises, J. Economic Management. 24 (2007)15-19.

[3] Y.C. Luo, Review of employee participation in governance, J. The Journal of CPC Yunnan Provincial Committee School. 4 (2008) 158-160

[4] W.G. Yang, L. Tang, Strategy and implementation: human resource management and governance, J. Economic Management. 1 (2015) 37-40

[5] F. Luo, On incentive mechanism for project managers in state owned venture investment firms, J. Development Research. 5 (2010) 76-79

[6] Y.S. Sun, W.Z. Chen, Theory of property rights of human capital: review and research prospect, J. Science \& Technology Progress and Policy. 9 (2012) 152-156

[7] R. E. Freeman, Strategic Management: A Stakeholder Approach, MA: Pitman, Boston, 1984.

[8] J.Q. Chu, J.H. Li, Theory and practice of employee participation in corporate governance, J. Statistics and Decision. 6 (2004) 121-122.

[9] H.J. Hu, Y.J. Guo, Employees' participation in corporate governance: practice abroad and countermeasures of China, J. Journal of Zhongzhou University. 7 (2005) 28-30.

[10] H. Song, Z.W. Ni, J.Z. Zhu, W.W. Zhu, Harmonious co-determination mechanism based on virtual stock holding: a case study of employees' participation in corporate governance in state owned enterprises of China, J. Communication of Finance and Accounting. 10 (2009) 64-69.

[11] A. Mitchell, D. Wood, Toward a theory of stakeholder dentification and salience: defining the principle of who and what really counts, J. Academy of Management Review. 22 (1997) 853-88. 